\title{
PENGARUH LITERASI KEUANGAN DAN ANTESEDENNYA TERHADAP TOLERANSI RISIKO DENGAN MODERASI FAKTOR DEMOGRAFI PADA PEKERJA MUDA DI INDONESIA
}

\author{
Fitriani Marfuah Permanasari \\ Fakultas Ekonomi Universitas Negeri Jakarta \\ Email: fitri0612@gmail.com \\ Harya Kuncara \\ Fakultas Ekonomi Universitas Negeri Jakarta \\ Email: har_kun@yahoo.com \\ Ari Warokka \\ Fakultas Ekonomi Universitas Negeri Jakarta \\ Email: ari.warokka@gmail.com
}

\begin{abstract}
ABSTRAK
Penelitian ini bertujuan untuk melihat pengaruh literasi keuangan dan antesedennya terhadap toleransi risiko dengan moderasi faktor demografi pada pekerja muda di Indonesia. Anteseden dalam penelitian ini menggunakan Pendidikan Keuangan, Pengetahuan Keuangan, Sikap Keuangan dan Perilaku Keuangan. Penelitian dimoderasi oleh faktor demografi yaitu jenis kelamin dan status pernikahan. Penelitian dilakukan terhadap 580 pekerja muda di Indonesia khususnya di JABODETABEK melalui survey online (google-form). Metode penelitian yang digunakan dalam penelitian ini menggunakan pendekatan kuantitatif menggunakan teknik SEM (Structural Equation Modeling), untuk menguji efek moderasi peneliti menggunakan Multigrup Analysis. Penelitian ini menghasilkan bahwa literasi keuangan dan anteseden memiliki pengaruh positif pada toleransi risiko, sedangkan faktor demografi seperti jenis kelamin dan status pernikahan masing-masing memiliki pengaruh pada toleransi risiko.
\end{abstract}

Kata kunci : Pendidikan Keuangan, Pengetahuan Keuangan, Sikap Keuangan, Perilaku Keuangan, Toleransi Risiko 


\section{PENDAHULUAN}

Kaum muda saat ini banyak menjadi tema yang dibahas dari berbagai aspek kehidupan, tak terlepas dari sektor finansial. Banyak kalangan yang berpandangan bahwa kaum muda kurang menyadari pentingnya berinvestasi. Sebanyak 70 persen kaum muda menggunakan uangnya untuk travelling dan memenuhi gaya hidup yang mereka inginkan. Hanya sedikit kaum muda yang memiliki kesadaran untuk mengalokasikan uangnya dalam investasi. Akibatnya, banyak kaum muda yang di masa tua tidak bisa menikmati hasil jerih payahnya di waktu muda. Banyak alasan mengapa kaum muda enggan berinvestasi. Salah satunya kurangnya edukasi tentang investasi pada kaum muda membuat mereka alergi dengan yang namanya investasi (Riris, 2019).

Tidak semua investasi adalah investasi yang baik dan tergantung pada risikonya, dan untuk memahami risiko investasi maka sejalan dengan memahami toleransi risiko personal. Toleransi risiko adalah faktor penting yang mempengaruhi berbagai keputusan keuangan (Roszkowski dan Snelbecker, 1990). Droms (1987) dalam (Karninta, 2013) menemukan bahwa Toleransi Risiko merupakan salah satu faktor penentu komposisi yang tepat dalam sebuah investasi yang optimal berdasarkan kebutuhan setiap individu dalam memandang risk dan return.

Toleransi risiko atau Risk Tolerance bisa diartikan sebagai keinginan individu untuk terlibat dalam kegiatan keuangan yang hasil tidak pasti (Duda et al., 2010). Salah satu faktor yang mempengaruhi toleransi risiko adalah pengetahuan mengenai risiko itu sendiri. Cordel (2001) bahkan menemukan bahwa pengetahuan risiko (risk knowledge) merupakan elemen penting dalam menilai toleransi risiko seseorang. Untuk itu memiliki pemahaman finansial atau literasi keuangan sangat diperlukan dalam menganalisa suatu keputusan keuangan yang berisiko. Individu dengan tingkat literasi keuangan serta tingkat toleransi terhadap risiko yang tinggi cenderung akan menabung untuk hari tuanya dibandingkan dengan individu dengan tingkat literasi keuangan serta toleransi terhadap risiko yang rendah (Jacob-Lawson dan Hershey 2005). 
Literasi keuangan sendiri didefinsisikan sebagai pengetahuan dan pemahaman atas konsep dan risiko keuangan, berikut keterampilan, motivasi, serta keyakinan untuk menerapkan pengetahuan dan pemahaman tersebut untuk membuat keputusan keuangan yang efektif, meningkatkan kesejahteraan keuangan (financial well being) individu dan masyarakat, serta berpartisipasi dalam bidang ekonomi (Organisation for Economic Co-operation and Development atau OECD (2016).

Secara logis, seseorang dengan pendidikan finansial yang baik dapat membuat keputusan yang lebih baik bagi keluarga mereka, meningkatkan keamanan ekonomi dan kesejahteraan mereka. Keluarga yang aman lebih mampu berkontribusi pada komunitas yang penting dan berkembang, lebih jauh mendorong perkembangan ekonomi masyarakat (Hogarth, 2006).

Seseorang dengan pendidikan yang lebih baik, memiliki lebih banyak peluang untuk bekerja dan mensejahterakan hidupnya. Karakteristik ketenagakerjaan di Indonesia hingga saat ini masih didominasi oleh penduduk dengan tingkat pendidikan rendah. Berdasarkan Data Badan Pusat Statistik mengenai Keadaan Ketenagakerjaan Indonesia Februari 2018 No. 42/05/Th. XXI, 07 Mei 2018, tenaga kerja Indonesia hingga Februari 2018 didominasi oleh penduduk berpendidikan rendah (SMP ke bawah) sebanyak 75,99 juta orang (59,80 persen). Sementara itu, penduduk berpendidikan menengah (SMA sederajat) sebanyak 35,87 juta orang (28,23 persen). Penduduk berpendidikan tinggi hanya sebanyak 15,21 juta orang (11,97 persen) mencakup 3,50 juta orang berpendidikan Diploma dan 11,71 juta orang berpendidikan Universitas.

Rendahnya pendidikan sebagian besar pekerja di Indonesia mengarah pula kepada rendahnya pengetahuan mereka terkait keuangan. Seseorang menunjukkan tingkat melek finansial yang lebih tinggi ketika dihadapkan pada pengetahuan keuangan yang lebih tinggi melalui pendidikan formal, serta pengaruh teman sebaya dan keluarga. Meskipun teori dampak sosial dapat menjelaskan mengapa individu akan dipengaruhi oleh orang lain, efek endapan individu pada lingkungan sosial mereka dan konsekuensi dinamis tidak dipertimbangkan oleh teori asli (Nowak et al., 1990). 
Berdasarkan hasil survey OECD-INFE (2017) yang digunakan untuk melihat literasi keuangan ke dalam tiga dimensi, yaitu pengetahuan keuangan, perilaku keuangan, dan sikap keuangan pada 101.596 orang dewasa berusia 18 hingga 79 tahun di 21 negara, skor rata-rata Pengetahuan Keuangan, Sikap Keuangan dan Perilaku Keuangan di negara-negara G20 sebesar 12,7 dari total skor 21 (terdiri dari total 7 poin untuk Pengetahuan Keuangan, 9 poin untuk Perilaku Keuangan dan 5 poin untuk Sikap Keuangan), dimana Indonesia berada di atas skor rata-rata dengan total skor sebesar 13.4. Hal ini mengindikasikan bahwa literasi keuangan Indonesia termasuk ke dalam kategori cukup.

Hal ini sejalan dengan Survei Nasional Literasi dan Inklusi Keuangan (SNLIK) yang dilakukan oleh Otoritas Jasa Keuangan (OJK) menunjukkan bahwa indeks literasi keuangan Indonesia pada tahun 2016 meningkat dari 21,84\% di tahun 2013 menjadi 29,66\%, yang berarti dari setiap 100 penduduk Indonesia hanya sekitar 30 orang yang termasuk ke kategori well literate. Hal tersebut menunjukkan bahwa terjadi peningkatan pemahaman keuangan (well literate) di tahun 2016.

Namun, literasi keuangan lebih dari sekedar pendidikan keuangan (Potrich et al., 2015). Literasi keuangan merupakan ukuran tentang seberapa baik seorang individu dapat memahami dan menggunakan informasi terkait keuangan pribadi (Huston, 2010). Menurut Hung et al. (2009) literasi keuangan terdiri dari pengetahuan keuangan, sikap keuangan, perilaku keuangan dan kemampuan untuk membuat keputusan keuangan.Beberapa peneliti mengemukakan bahwa untuk membentuk literasi keuangan, diperlukan beberapa faktor, yaitu pengetahuan keuangan Hung et al. (2009), sikap keuangan Hung et al. (2009), perilaku keuangan, dan pendidikan keuangan.

Pendidikan keuangan (Financial Education) adalah proses pembangunan untuk memfasilitasi orang untuk membuat keputusan yang benar dan dengan demikian berhasil mengelola keuangan pribadi. Kebanyakan individu mengutip pengalaman pribadi mereka sebagai sumber yang paling penting dari belajar keuangan mereka (Vieira, Potrich and Mendes-Da-Silva (2018). 
Pengetahuan keuangan atau Financial Knowledge termasuk dalam 'pemahaman' keuangan dan 'penggunaan' terhadap pemahaman tersebut (Huston, 2010). (Hilgert et al., 2003) serta (Cude et al., 2006) menyatakan bahwa diperlukan pengetahuan tentang bagaimana mengelola keuangan serta bagaimana teknik berinvestasi menjadi hal yang tidak dapat diabaikan lagi seperti waktuwaktu sebelumnya.

Sikap keuangan adalah ukuran keadaan pikiran anda, pendapat anda dan penilaian tentang dunia di mana anda hidup (Pankow, 2003). Mereka mencerminkan posisi yang telah anda ambil dengan nilai-nilai anda dan jauh lebih fleksibel daripada nilai-nilai. Sedangkan (Hayhoe et al., 1999) Menyatakan bahwa ada suatu hubungan antara Sikap Keuangan dan tingkat masalah keuangan. Dengan demikian dapat dikatakan bahwa sikap keuangan seseorang juga berpengaruh terhadap cara seseorang mengatur perilaku keuangnnya.

Perilaku keuangan menurut Hersh Shefrin (2010) mendefinisikan behaviour finance adalah studi yang mempelajari bagaimana fenomena psikologi mempengaruhi tingkah laku keuangannya. Khususnya, mempelajari bagaiamana psikologi mempengaruhhi keputusan keuangan, perusahaan dan pasar keuangan. Sedangkan Sedangkan Menurut Hung et al yang dikutip oleh (Chen-Chen Yong, Siew-Yong Yew, 2015) perilaku keuangan dan kemampuan individu dipengaruhi oleh pengetahuan keuangan dan kepercayaan diri yang mungkin tidak berkorelasi dengan pengetahuan yang sebenarnya.

Hasil penelitian (Chen-Chen Yong, Siew-Yong Yew, 2015) pertama pendidikan keuangan memiliki pengaruh signifikan dan posistif terhadap pengetahuan keuangan. Kedua, mengungkapkan bahwa pengetahuan keuangan secara signifikan dan berhubungan positif dengan perlaku keuangan. Namun, penelitian ini menemukan bahwa itu adalah hubungan langsung antara pengetahuan keuangan dan perilaku yang signifikan. Dengan kata lain, sikap memainkan peran utama dalam mengkonversi pengetahuan untuk perilaku yang mengrah ke hasil yang lebih baik.

Pentingnya literasi keuangan pada kaum muda ditunjukkan pada penelitian (Chen-Chen Yong, Siew-Yong Yew, 2015) dimana literasi keuangan dan praktek 
manajemen keuangan yang kurang baik mempengaruhi banyak anak muda di Malaysia dan oleh karena itu, pendidikan keuangan sangat penting untuk membimbing perilaku keuangan mereka. Lebih lanjut, ditemukan bahwa sikap keuangan memidiasi pengaruh pengetahuan keuangan terhadap perilaku dan kerenanya, kaum muda perlu memiliki sikap yang benar untuk mengambil manfaat dari pengetahuan keuangan.

Konsekuensi jangka pendek, menengah, dan panjang yang tidak diinginkan dari perilaku manajemen keuangan yang tidak memadai tidak hanya mempengaruhi individu, tetapi juga rumah tangga, dan pada akhirnya menghasilkan berbagai peristiwa yang tidak diinginkan di seluruh masyarakat (Fenton et al., 2016). Misalnya, perilaku keuangan yang tidak memadai dapat menyebabkan utang sementara atau kronis, ketidakmampuan membayar utang atau mengajukan kebangkrutan, dan perilaku tersebut disebabkan oleh faktor ekonomi bersama dengan faktor psikologis. Chen-Chen Yong, Siew-Yong Yew, (2015) menemukan bahwa etnis, umur, penghasilan, pendidikan, keandalan pendapatan dan pengetahuan keuangan memainkan peran yang signifikan pada perilaku manajemen keuangan individu secara keseluruhan.

Dengan demikian pembentukan pemahaman keuangan yang baik untuk menilai toleransi risiko keuangan individu, perlu juga mempertimbangkan faktorfaktor lain seperti faktor demografi. Orang dengan penghasilan yang rendah memiliki perilaku manajemen keuangan yang buruk. Sedangkan orang dengan kelompok usia 20-49 memiliki kemampuan finansial yang lebih buruk dibanding usia 30-39. Hal ini sejalan dengan penelitian yang dilakukan oleh (Putri and Rahyuda, 2017) sementara itu, (Pertiwi, mega mutiara, 2018) yang melakukan penelitian yang berjudul pengaruh faktor demografi terhadap jenis investasi dan perilaku investor di pasar modal. Hasil dari penelitian tersebut dikemukakan bahwa faktor demografi yang meliputi jenis kelamin, etnis, usia, status, pendidikan terakhir, pekerjaan, anggota keluarga, pengeluaran per bulan, pengalaman investasi dan frekuensi transaksi investor tidak mempunyai pengaruh signifikan dengan jenis investasi. 
Lown (2008) dalam Sina (2014) menemukan bahwa terjadi perbedaan kepribadian antara perempuan terkait tabungan pensiun dan 10 juga toleransi risiko. Hal ini menyebabkan perilaku keuangan pun menjadi berbeda sehingga secara keseluruhan hasil penelitian menemukan bahwa perempuan membutuhkan pendidikan tentang risiko, dampak dari waktu terhadap nilai uang dan yang signifikan yaitu membutuhkan pembuatan tujuan keuangan yang benar.

Berdasarkan hal tersebut maka terdapat gap penelitian, dimana faktor demografi perlu juga diuji sebagai efek yang melemahkan atau memperkuat pengaruh financial literacy terhadap toleransi risiko. Sehingga faktor demografi dapat difungsikan sebagai variabel moderating. Selain itu, pemilihan subjek penelitian yaitu pekerja usia muda di Indonesia adalah untuk melihat bagaimana tingkat literasi keuangan dan toleransi risiko responden yang memiliki penghasilan sendiri dan dalam usia yang produktif. Dengan demikian, maka penelitian ini bertujuan untuk melihat pengaruh faktor-faktor yang mempengaruhi financial literacy seperti, Pengetahuan Keuangan, Pendidikan Keuangan, Sikap Keuangan, Perilaku Keuangan dan Toleransi Risiko baik secara langsung maupun tidak langsung dengan mempertimbangkan faktor demografi (Gender dan Marital Status) sebagai moderating variabel terhadap pekerja usia muda di Indonesia.

\section{Rumusan Masalah}

Berdasarkan latar belakang masalah yang dikemukakan di atas, maka rumusan masalah adalah dalam penelitian ini diajukan dalam pertanyaan penelitian sebagai berikut: 1). Apakah Pendidikan Keuangan mempengaruhi Pengetahuan Keuangan Pekerja muda di Indonesia? 2). Apakah Pengetahuan Keuangan mempengaruhi Sikap Keuangan Pekerja muda di Indonesia? 3). Apakah Pengetahuan Keuangan mempengaruhi Perilaku Keuangan Pekerja muda di Indonesia? 4). Apakah Sikap Keuangan mempengaruhi Perilaku Keuangan Pekerja muda di Indonesia? 5). Apakah Pengetahuan Keuangan mempengaruhi Perilaku Keuangan melalui Sikap Keuangan Pekerja muda di Indonesia? 6). Apakah Perilaku Keuangan mempengaruhi financial literacy Pekerja muda di Indonesia? 7). Apakah financial literacy mempengaruhi Toleransi Risiko Pekerja muda di Indonesia? 8). Apakah terdapat pengaruh perbedaan jenis kelamin antara 
pengaruh financial literacy terhadap Toleransi Risiko Pekerja muda di Indonesia? 9). Apakah terdapat pengaruh perbedaan status pernikahan antara pengaruh financial literacy terhadap Toleransi Risiko Pekerja muda di Indonesia?

\section{Tujuan Penelitian}

Berdasarkan rumusan masalah yang telah dikemukakan di atas, maka tujuan dari penelitian ini ditetapkan sebagai berikut: 1). Untuk mengetahui pengaruh Pendidikan Keuangan mempengaruhi Pengetahuan Keuangan Pekerja muda di Indonesia. 2). Untuk mengetahui pengaruh Pengetahuan Keuangan mempengaruhi Sikap Keuangan Pekerja muda di Indonesia. 3). Untuk mengetahui pengaruh Pengetahuan Keuangan mempengaruhi Perilaku Keuangan Pekerja muda di Indonesia. 4). Untuk mengetahui pengaruh Sikap Keuangan mempengaruhi Perilaku Keuangan Pekerja muda di Indonesia. 5). Untuk mengetahui pengaruh Pengetahuan Keuangan mempengaruhi Perilaku Keuangan melalui Sikap Keuangan Pekerja muda di Indonesia. 6). Untuk mengetahui pengaruh Perilaku Keuangan mempengaruhi financial literacy Pekerja muda di Indonesia. 7). Untuk mengetahui pengaruh financial literacy mempengaruhi Toleransi Risiko Pekerja muda di Indonesia. 8). Untuk mengetahui pengaruh perbedaan jenis kelamin antara pengaruh financial literacy terhadap Toleransi Risiko Pekerja muda di Indonesia. 9). Untuk mengetahui pengaruh perbedaan status pernikahan antara pengaruh financial literacy mempengaruhi Toleransi Risiko Pekerja muda di Indonesia.

\section{TELAAH PUSTAKA}

\section{Toleransi Risiko}

Risiko adalah ketidakpastian tentang peristiwa masa depan atas hasil yang diinginkan atau tidak diinginkan (Griffin, 2002). Dalam domain pengambilan keputusan keuangan, toleransi risiko keuangan umumnya didefinisikan sebagai jumlah maksimum ketidakpastian yang bersedia diterima seseorang ketika membuat keputusan keuangan (Grable and Joo, 2004). Toleransi risiko keuangan 
juga memengaruhi cara orang menginvestasikan sumber dayanya untuk tujuan jangka pendek dan jangka panjang, seperti menabung untuk pembelian barang ataupun tabungan pensiun. Sangat masuk akal untuk berharap bahwa orang-orang dengan berbagai tingkat toleransi risiko harus bertindak secara berbeda ketika membuat keputusan investasi, dengan mereka yang memiliki toleransi risiko tinggi (keengganan terhadap risiko rendah) untuk berinvestasi lebih agresif (Grable, 2016).

\section{Literasi Keuangan}

Menurut definisi paling dasar, literasi keuangan berkaitan dengan kompetensi seseorang dalam mengelola uang (Remund, 2010). Istilah literasi keuangan juga mengacu pada seperangkat keterampilan dan pengetahuan individu yang memungkinkannya membuat keputusan yang tepat dan efektif melalui pemahaman tentang keuangan (Sinha and Gupta, 2013). Yong, Yew dan Wee (2018) menginvestigasi Literasi keuangan dari perspekctif perilaku berdasarkan Theory of Planned Behaviour (TPB). Dengan demikian, literasi keuangan dikonseptualisasikan sebagai proses perkembangan yang berakar pada teori perkembangan kognitif dan teori kognitif social. Berdasarkan teori TPB, perilaku seseorang ditentukan oleh sikap, norma subjektif dan persepsi kontrol, didukung oleh niat perilakunya (Ajzen, 1991). Maka untuk memahami tingkat literasi keuangan seseorang, sangat penting untuk memahami bagaimana TPB dapat menjelaskan perilaku seseorang. Maksud dari TPB adalah sebagai prediktor terbaik perilaku yang pada gilirannya ditentukan oleh sikap dan persepsi normatif sosial terhadap perilaku tersebut (Yong, Yew dan Wee, 2018).

\section{Anteseden Literasi Keuangan}

Literasi keuangan dibentuk oleh serangkaian konstruksi yang saling terkait yang terkait dengan karakteristik sosial-ekonomi dan perilaku keuangan (Hung et al., 2009). Lebih lanjut, Hung, Parker and Yoong, (2009) menyatakan bahwa anteseden financial literacy terdiri dari pengetahuan keuangan dan kemampuan membuat keputusan keuangan. Sedangkan Santini et al., (2019) mendefinisikan tujuh konstruksi awal dari literasi keuangan, yaitu tingkat pendidikan, sikap 
keuangan, pengetahuan keuangan, perilaku keuangan, gender, pendapatan rumah tangga dan investasi. Penelitian baru-baru ini oleh Yong, Yew and Wee (2018) meneliti literasi keuangan ke dalam empat anteseden yaitu: (1) Pendidikan keuangan, (2) Pengetahuan keuangan, (3) Sikap keuangan, dan (4) Perilaku keuangan.

\section{Pendidikan Keuangan}

Pendidikan Keuangan adalah strategi intervensi yang digunakan oleh kelompok kepentingan konsumen, pendidik keuangan dan pembuat kebijakan untuk meningkatkan dan membangun pengetahuan keuangan konsumen (Loke, 2015). Potrich, Vieira and Mendes-Da-Silva (2016) mendefinisikan pendidikan keuangan sebagai proses pengembangan untuk memfasilitasi orang untuk membuat keputusan yang benar dan untuk mengelola keuangan pribadi dengan baik.

\section{Pengetahuan Keuangan}

Huang, Nam dan Sherraden (2013) mendefinisikan pengetahuan keuangan sebagai pemahaman individu tentang konsep keuangan. Huston (2010) mengidentifikasi empat konsep utama pengetahuan keuangan kedalam konsep uang dasar, konsep tabungan atau investasi, pinjaman dan perlindungan. Lusardi and O. S. Mitchell, (2011) menyatakan bahwa seseorang yang tingkat literasi keuangannya rendah biasanya berkorelasi dengan penghasilan rendah, pendidikan rendah, dan kekayaan yang rendah. Oleh karena itu, peningkatan pengetahuan keuangan bagi rumah tangga diperlukan agar mereka dapat berpartisipasi secara berkelanjutan di pasar uang (Ramachandran, 2011).

\section{Sikap Keuangan}

Rajna et al., (2011) mengonseptualisasikan sikap keuangan sebagai penerapan prinsip-prinsip keuangan untuk menciptakan dan mempertahankan nilai melalui pengambilan keputusan dan manajemen sumber daya yang tepat. Sikap keuangan yang baik dapat diukur dengan lima komponen dari kemampuan seseorang menunjukkan pola pikir yang baik tentang uang (obsession), mampu 
mengontrol situasi keuangan yang dimiliki (effort), menyesuaikan penggunaan uang terhadap kebutuhan (inadequancy), tidak ingin menghabiskan uang (retention), memiliki pandangan luas terhadap uang (securities) (Herdjiono and Damanik, 2016). Dengan demikian, sikap keuangan (financial attitude) merupakan salah satu elemen penting dalam literasi keuangan. Jika seseorang memiliki sikap negatif dalam menabung untuk masa depan mereka, maka mereka akan cenderung kurang melakukan perilaku seperti itu. Demikian pula, jika mereka lebih suka memprioritaskan keinginan jangka pendek, maka mereka tidak mungkin menyediakan tabungan darurat atau membuat rencana keuangan jangka panjang (Atkinson and Messy, 2012).

\section{Perilaku Keuangan}

Cara seseorang berperilaku akan memiliki dampak signifikan pada kesejahteraan finansial mereka. Oleh karena itu penting untuk menangkap bukti perilaku keuangan dalam mengukur literasi keuangan (Atkinson and Messy, 2012). Perilaku Keuangan mengacu pada bagaimana seseorang berperilaku dalam kaitannya dengan hal keuangan pribadi,diukur dengan tindakan individu tersebut (Marsh, 2006). Sedangkan menurut Ricciardi dan Simon (2000), Perilaku Keuangan adalah suatu disiplin ilmu yang di dalamnya melekat interaksi berbagai disiplin ilmu dan secara terus menerus berintegrasi sehingga pembahasannya tidak dilakukan isolasi.

\section{Faktor Demografi}

Faktor demografi termasuk status pekerjaan, status perkawinan, pendapatan, jenis pekerjaan, usia, jenis kelamin, pengalaman pekerjaan, dan tingkat pendidikan. Menurut Robb dan Woodyard, (2011) Banyak program keuangan yang ditargetkan pada keadaan sosial demografi, penelitian ini menunjukkan bahwa ada perbedaan dalam perilaku keuangan pada sosial demografi dari tingkat pengetahuan. Dengan demikian dapat diasumsikan bahwa perbedaan pada faktor demografi dapat memberikan pengaruh literasi keuangan dan juga pada toleransi risiko. Terkait dengan hal tersebut, maka factor demografi akan difungsikan 
sebagai variabel moderating yang mempengaruhi hubungan antara finansial literasi dengan toleransi risiko.

Faktor demografi yang akan digunakan dalam penelitian ini adalah jenis kelamin dan status pernikahan yang dapat dijelaskan sebagai berikut:

1. Jenis kelamin (Gender)

Secara terminologi menurut Elfi Muawanah (2009:2) gender/jenis kelamin diartikan sebagai konsep yang berkaitan dengan peran laki-laki dan perempuan di suatu waktu dan budaya tertentu yang dikonstruksi secara sosial bukan secara biologis. Jenis kelamin dapat menentukan akses terhadap pendidikan, pekerjaan, kesehatan, harapan hidup, serta kebebasan hidup seseorang. Dari hal tersebut dapat dipahami bahwa gender merupakan salah satu faktor penting bagi individu untuk membuat keputusan dalam kehidupannya baik secara sosial maupun ekonomi.

2. Status Pernikahan (Marital Status)

Status pernikahan adalah status yang diperoleh secara hukum akibat ikatan pernikahan, sehingga individu yang belum memiliki ikatan ini berarti memiliki status belum menikah atau lajang.

\section{Model Penelitian}

Berdasarkan kerangka teoritik dan perumusan hipotesis yang telah dikemukakan di atas, maka model penelitian yang diajukan dapat terlihat pada gambar berikut di bawah ini.

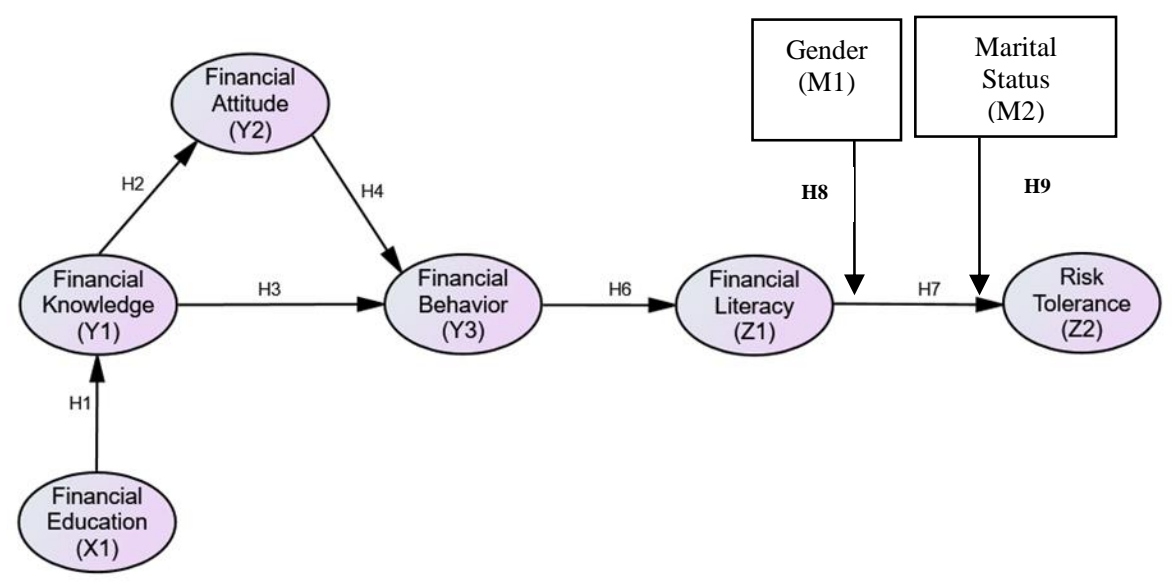




\section{Perumusan Hipotesis Penelitian}

Hipotesis disusun berdasarkan teori dan kerangka berpikir yang sudah diuraikan sebelumnya, maka dari teori dan kerangka berpikir dapat disusun beberapa hipotesis sebagai berikut:

1. H1 : Terdapat pengaruh Pendidikan Keuangan terhadap Pengetahuan Keuangan.

2. H2 : Terdapat pengaruh Pengetahuan Keuangan terhadap Sikap Keuangan.

3. H3 : Terdapat pengaruh Pengetahuan Keuangan terhadap Perilaku Keuangan.

4. H4 : Terdapat pengaruh Sikap Keuangan terhadap Perilaku Keuangan.

5. H5: Terdapat pengaruh Pengetahuan Keuangan terhadap Perilaku Keuangan melalui Sikap Keuangan.

6. H6: Terdapat pengaruh Perilaku Keuangan terhadap Financial Literacy

7. H7 : Terdapat Pengaruh Financial Literacy terhadap Toleransi Risiko.

8. H8 :Terdapat Pengaruh Perbedaan Jenis Kelamin antara pengaruh Financial Literacy terhadap Toleransi Risiko.

9. H9 : Terdapat Pengaruh Perbedaan Status Pernikahan antara pengaruh Financial Literacy terhadap Toleransi Risiko.

\section{HASIL DAN PEMBAHASAN}

\section{Karakteristik Responden}

Peneliti menggunakan profil responden untuk mengetahui komposisi responden yang berpatisipasi dalam penelitian ini. Deskripsi karakteristik responden tersaji pada tabel 1 . 
Tabel 1. Deskriptif Karakteristik Responden

\begin{tabular}{|c|c|c|c|}
\hline & Karakteristik Responden & frekuensi & $\%$ \\
\hline \multirow{4}{*}{ Usia } & 16 - 20 Tahun & 25 & 4,3 \\
\hline & 21 - 25 Tahun & 199 & 34,3 \\
\hline & 26 - 30 Tahun & 356 & 61,4 \\
\hline & \multirow[t]{2}{*}{ Total } & 580 & 100,0 \\
\hline \multirow{3}{*}{$\begin{array}{l}\text { Jenis } \\
\text { Kelamin }\end{array}$} & & 316 & 54,5 \\
\hline & Wanita & 264 & 45,5 \\
\hline & Total & $\mathbf{5 8 0}$ & 100,0 \\
\hline \multirow{4}{*}{$\begin{array}{l}\text { Status } \\
\text { Pernikahan }\end{array}$} & Belum Menikah & 234 & 40,3 \\
\hline & Janda/Duda, Cerai/mati & 2 & 0,3 \\
\hline & Menikah & 344 & 59,3 \\
\hline & Total & $\mathbf{5 8 0}$ & 100,0 \\
\hline \multirow{4}{*}{ Pendidikan } & SMA & 26 & 4,5 \\
\hline & Sarjana/ D IV & 537 & 92,6 \\
\hline & Magister/ Pascasarjana & 17 & 2,9 \\
\hline & Total & 580 & 100,0 \\
\hline \multirow{4}{*}{ Lama Berja } & 1 - 3 Tahun & 422 & 72,8 \\
\hline & 3 - 5 Tahun & 112 & 19,3 \\
\hline & $>5$ Tahun & 46 & 7,9 \\
\hline & Total & 580 & 100,0 \\
\hline \multirow{4}{*}{ Pendapatan } & Rp 3.500.000 - Rp 4.999.999 & 364 & 62,8 \\
\hline & Rp 5.000.000 - Rp 9.999.999 & 190 & 32,8 \\
\hline & $\geq \operatorname{Rp} 10.000 .000$ & 26 & 4,5 \\
\hline & Total & 580 & 100,0 \\
\hline
\end{tabular}

Sumber: data primer dioleah peneliti (2020) 
Berdasarkan Tabel diatas diketahui bahwa usia responden didominasi oleh usia 26 - 30 Tahun sebanyak 356 responden (61,4\%). Responden juga didominasi oleh jenis kelamin pria adalah sebanyak 316 responden (54,5\%). Sebagian besar responden juga berstatus menikah sebanyak 344 responden (59,3\%). Kemudian sebagian besar responden menempuh pendidikan Sarjana/sederajat sebanyak 537 responden $(92,6 \%)$. Sacara statistik juga dapat dijelaskan bahwa sebagian besar responden memiliki lama bekerja dari 1 - 3 Tahun sebanyak 422 responden $(72,8 \%)$. Dari sisi pendapatan, responden sebagian besar memiliki tingkat pendapatan Rp. 3.500.000 - Rp. 4.999 .999 sebanyak 364 responden $(62,8 \%)$.

\section{Hasil Pengujian data}

\section{Uji Validitas}

Uji validitas dilakukan dengan cara membandingkan nilai $r$ hitung (pearson) dengan $\mathrm{r}$ tabel. Jika $\mathrm{r}$ hitung (pearson) lebih besar dari $\mathrm{r}$ tabel dan bernilai positif maka item tersebut valid dan dapat digunakan untuk penelitian dan jika $r$ hitung (pearson) lebih kecil dari $r$ tabel maka item yang tidak dapat digunakan dalam penelitian (Ghozali, 2016). Pengambilan keputusan berdasarkan pada nilai r hitung (Corrected Item-Total Correlation) > r tabel sebesar 0,0875, untuk $\mathrm{df}=500$ dan pada tingkat $\alpha=0,05$ (2 tailed). Hasil uji validitas data dapat dilihat pada Tabel 2 berikut.

Tabel 2 Hasil Uji Validitas

\begin{tabular}{|c|c|c|c|c|}
\hline Variabel & Indikator & r Hitung & r Tabel & Uji Validitas \\
\hline \multirow{10}{*}{ Risk Tolerance } & RT1 & $0,535 * *$ & 0,0875 & Valid \\
\hline & RT2 & $0,518 * *$ & 0,0875 & Valid \\
\hline & RT3 & $0,765^{* *}$ & 0,0875 & Valid \\
\hline & RT4 & $0,727 * *$ & 0,0875 & Valid \\
\hline & RT5 & $0,729 * *$ & 0,0875 & Valid \\
\hline & RT6 & $0,786 * *$ & 0,0875 & Valid \\
\hline & RT7 & $0,833 * *$ & 0,0875 & Valid \\
\hline & RT8 & $0,699 * *$ & 0,0875 & Valid \\
\hline & RT9 & $0,830 * *$ & 0,0875 & Valid \\
\hline & RT10 & $0,741 * *$ & 0,0875 & Valid \\
\hline \multirow{6}{*}{$\begin{array}{l}\text { Financial } \\
\text { Literacy }\end{array}$} & FL1 & $0,749 * *$ & 0,0875 & Valid \\
\hline & FL2 & $0,702 * *$ & 0,0875 & Valid \\
\hline & FL3 & $0,657 * *$ & 0,0875 & Valid \\
\hline & FL4 & $0,748 * *$ & 0,0875 & Valid \\
\hline & FL5 & $0,833 * *$ & 0,0875 & Valid \\
\hline & FL6 & $0,784 * *$ & 0,0875 & Valid \\
\hline
\end{tabular}




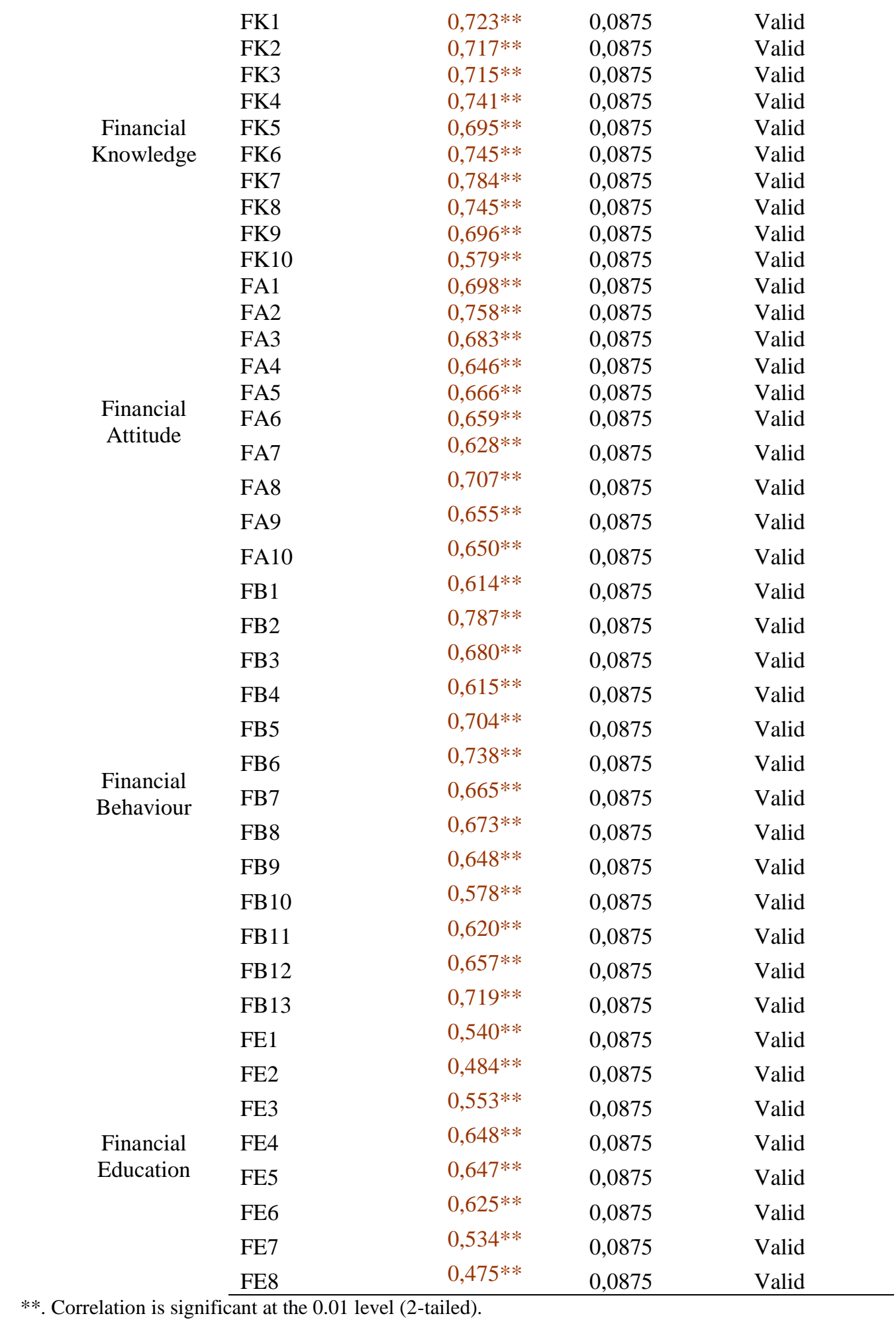

Sumber: Output SPSS 25 diolah peneliti (2020)

Pada aplikasi SPSS 25 tanda ** pada nilai $\mathrm{r}$ hitung (pearson correlation) sudah menunjukkan bahwa indikator tersebut valid pada level signifikansi 0.05 
(uji dua arah). Sehingga berdasarkan Tabel di atas dapat dikatakan bahwa itemitem yang digunakan dalam penelitian ini memiliki nilai $\mathrm{r}$ hitung $>0.0875$ dan memiliki tanda ** yang artinya butir-butir pernyataan dalam kuesioner telah valid.

\section{Uji Reliabilitas}

Uji reliabilitas data dilakukan secara one shot (pengukuran satu kali) menggunakan rumus Alpha Cronbach. Suatu variabel dikatakan memiliki tingkat reliabel tinggi jika nilai koefisien Crobach Alpha $(\alpha)>0,70$ (Ghozali, 2016). Hasil uji reliabilitas dapat dilihat pada tabel sebagai berikut.

Tabel 3 Hasil Uji Reliabilitas

\begin{tabular}{cccc}
\hline Variabel & Cronbach Alpha & Cut off value & Reliabilitas \\
\hline Toleransi Risiko & 0,898 & 0,70 & Reliabel \\
Literasi Keuangan & 0,835 & 0,70 & Reliabel \\
Pengetahuan Keuangan & 0,892 & 0,70 & Reliabel \\
Sikap Keuangan & 0,860 & 0,70 & Reliabel \\
Perilaku Keuangan & 0,896 & 0,70 & Reliabel \\
Pengetahuan Keuangan & 0,701 & 0,70 & Reliabel \\
\hline
\end{tabular}

Sumber: Output SPSS 25 diolah peneliti (2020)

Tabel 4.16 memperlihatkan bahwa seluruh variabel yang digunakan dalam penelitian ini dinyatakan konsisten atau stabil karena setiap variabel yang diteliti memiliki nilai Crobach Alpha $(\alpha)$ lebih besar dari 0,07.

Maka berdasarkan hasil pengujian validitas dan reliabilitas yang telah diuraikan, dapat disimpulkan bahwa seluruh pernyataan yang digunakan dalam penelitian ini sudah teruji kesahihan (validity) serta keandalannya (reliability) sehingga seluruh pernyataan layak digunakan sebagai alat ukur penelitian.

\section{Hasil Uji Hipotesis dengan Menggunakan SEM}

Berikut ini merupakan model dan tabel yang menunjukkan hasil pengujian hipotesis dalam penelitian menggunakan SEM-PLS. 


\section{Gambar 1 Hasil Uji Hipotesis}

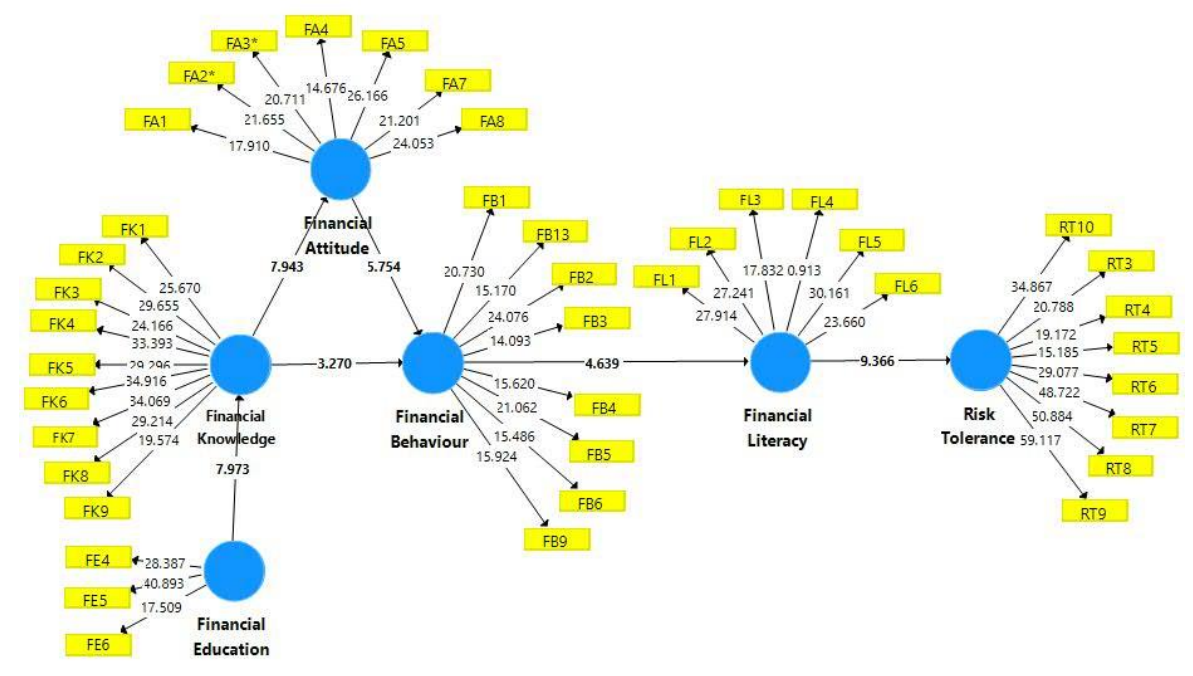

Tabel 4 Hasil Uji Hipotesis

\begin{tabular}{|c|c|c|c|c|c|c|}
\hline $\begin{array}{l}\text { Hipotes } \\
\text { is }\end{array}$ & Pengaruh & $\begin{array}{l}\text { Original } \\
\text { Sample }\end{array}$ & $\begin{array}{l}\text { T } \\
\text { Statistics }\end{array}$ & P Values & Hasil & Keputusan \\
\hline H1 & $\begin{array}{l}\text { Financial Education } \rightarrow \\
\text { Financial Knowledge }\end{array}$ & 0,3060 & 7,9729 & 0,0000 & $\begin{array}{l}\text { Signif } \\
\text { ikan }\end{array}$ & $\begin{array}{l}\text { Hipotesis } \\
\text { diterima }\end{array}$ \\
\hline $\mathrm{H} 2$ & $\begin{array}{l}\text { Financial Knowledge } \\
\rightarrow \text { Financial Attitude }\end{array}$ & 0,3966 & 7,9434 & 0,0000 & $\begin{array}{l}\text { Signif } \\
\text { ikan }\end{array}$ & $\begin{array}{l}\text { Hipotesis } \\
\text { diterima }\end{array}$ \\
\hline H3 & $\begin{array}{l}\text { Financial Knowledge } \\
\rightarrow \text { Financial Behaviour }\end{array}$ & 0,1648 & 3,2703 & 0,0011 & $\begin{array}{l}\text { Signif } \\
\text { ikan }\end{array}$ & $\begin{array}{l}\text { Hipotesis } \\
\text { diterima }\end{array}$ \\
\hline $\mathrm{H} 4$ & $\begin{array}{l}\text { Financial Attitude } \rightarrow \\
\text { Financial Behaviour }\end{array}$ & 0,3668 & 5,7538 & 0,0000 & $\begin{array}{l}\text { Signif } \\
\text { ikan }\end{array}$ & $\begin{array}{l}\text { Hipotesis } \\
\text { diterima }\end{array}$ \\
\hline H5 & $\begin{array}{l}\text { Financial Knowledge } \\
\rightarrow \text { Financial Attitude } \\
\rightarrow \text { Financial } \\
\text { Behaviour }\end{array}$ & 0,1455 & 4,6968 & 0,0000 & $\begin{array}{l}\text { Signif } \\
\text { ikan }\end{array}$ & $\begin{array}{l}\text { Hipotesis } \\
\text { diterima }\end{array}$ \\
\hline H6 & $\begin{array}{l}\text { Financial Behaviour } \\
\rightarrow \text { Financial Literacy }\end{array}$ & 0,2530 & 4,6392 & 0,0000 & $\begin{array}{l}\text { Signif } \\
\text { ikan }\end{array}$ & $\begin{array}{l}\text { Hipotesis } \\
\text { diterima }\end{array}$ \\
\hline H7 & $\begin{array}{l}\text { Financial Literacy } \rightarrow \\
\text { Risk Tolerance }\end{array}$ & 0,3542 & 9,3659 & 0,0000 & $\begin{array}{l}\text { Signif } \\
\text { ikan }\end{array}$ & $\begin{array}{l}\text { Hipotesis } \\
\text { diterima }\end{array}$ \\
\hline
\end{tabular}

Sumber: Output SmartPLS 3.2.9, diolah peneliti (2020)

Berdasarkan tabel 4 di atas menunjukkan bahwa uji hipotesis $\mathrm{H} 1$ mengenai pengaruh variabel Financial Education terhadap variabel Financial Knowledge menghasilkan nilai t-statistik 7,9729 > 1,960 dan p values sebesar 0,000<0,05, sehingga hasilnya signifikan. Dengan demikian Hipotesis H1 diterima. 
Uji hipotesis H2 mengenai pengaruh variabel Financial Knowledge terhadap variabel Financial Attitude menghasilkan nilai t-statistik 7,9434> 1,960 dan $\mathrm{p}$ values sebesar $0,000<0,05$, sehingga hasilnya signifikan. Dengan demikian Hipotesis $\mathrm{H} 2$ diterima.

Uji hipotesis H3 mengenai pengaruh variabel Financial Knowledge terhadap variabel Financial Behavior menghasilkan nilai t-statistik 3,2703 > 1,960 dan $\mathrm{p}$ values sebesar 0,011 <0,05, sehingga hasilnya signifikan. Dengan demikian Hipotesis H3 diterima.

Uji hipotesis H4 mengenai pengaruh variabel Financial Attitude terhadap variabel Financial Behaviour menghasilkan nilai t-statistik 5,7538>1,960 dan p values sebesar $0,000<0,05$, sehingga hasilnya signifikan. Dengan demikian Hipotesis H4 diterima.

Uji hipotesis H5 mengenai pengaruh variabel Financial Knowledge terhadap variabel Financial Behaviour melalui variabel Financial Attitude menghasilkan nilai t-statistik 4,6968 > 1,960 dan p values sebesar 0,000 0,05, sehingga hasilnya signifikan. Dengan demikian Hipotesis H5 diterima.

Uji hipotesis H6 mengenai pengaruh variabel Financial Behaviour terhadap variabel Financial Literacy menghasilkan nilai t-statistik 4,6392 > 1,960 dan p values sebesar $0,000<0,05$, sehingga hasilnya signifikan. Dengan demikian Hipotesis H6 diterima.

Uji hipotesis H7 mengenai pengaruh variabel Financial Literacy terhadap variabel Risk Tolerance menghasilkan nilai t-statistik 9,3659>1,960 dan p values sebesar $0,000<0,05$, sehingga hasilnya signifikan. Dengan demikian Hipotesis $\mathrm{H} 7$ diterima.

\section{Uji Moderasi dengan Multi Group Analysis (MGA)}

Berikut adalah hasil pengujian hipotesis variabel Moderator dengan PLS MGA:

Tabel 5 Hasil Uji Moderasi dengan PLS-MGA

\begin{tabular}{ccccc}
\hline Hipotesis & $\begin{array}{c}\text { Untuk Variabel } \\
\text { Jenis Kelamin }\end{array}$ & $\begin{array}{c}\text { Path Coefficients-diff } \\
\text { (Men } \text { vs Women })\end{array}$ & $\begin{array}{c}p \text {-Value (Men vs } \\
\text { Women })\end{array}$ & Hasil \\
\hline H8 & $\begin{array}{l}\text { Financial } \\
\text { Literacy } \rightarrow \text { Risk }\end{array}$ & 0,0642 & $\mathbf{0 , 3 5 5 8}$ & $\begin{array}{c}\text { Tidak } \\
\text { Signifikan }\end{array}$ \\
\hline
\end{tabular}




\begin{tabular}{|c|c|c|c|c|}
\hline & Tolerance & & & \\
\hline Hipotesis & $\begin{array}{c}\text { Untuk Variabel } \\
\text { Status } \\
\text { Pernikahan }\end{array}$ & $\begin{array}{c}\text { Path Coefficients-diff } \\
\text { (Married vs Single) }\end{array}$ & $\begin{array}{c}\text { p-Value (Married vs } \\
\text { Single) }\end{array}$ & Hasil \\
\hline H9 & $\begin{array}{l}\text { Financial } \\
\text { Literacy } \rightarrow \text { Risk } \\
\text { Tolerance }\end{array}$ & $-0,0358$ & 0,6150 & $\begin{array}{c}\text { Tidak } \\
\text { Signifikan }\end{array}$ \\
\hline
\end{tabular}

Sumber: Output SmartPLS 3.2.9, diolah peneliti (2020)

Berdasarkan Tabel di atas, diketahui bahwa hasil uji hipotesis dengan pendekatan PLS-MGA untuk kedua variabel moderator, jenis kelamin dan status pernikahan, menghasilkan nilai $\mathrm{p}$ values secara berturut-turut adalah 0,3558 dan 0,6150 , yang keduanya bernilai di atas $0,05(\alpha>0,05)$. Hal ini mengindikasikan bahwa tidak ada perbedaan pengaruh jenis kelamin antara pengaruh literasi keuangan terhadap toleransi risiko. Demikian juga tidak ada perbedaan pengaruh status pernikahan antara pengaruh literasi keuangan terhadap toleransi risiko.

Untuk memperkuat hasil uji hipotesis dengan pendekatan PLS-MGA di atas, dan sebagai pengujian tambahan, maka peneliti juga melakukan Multi Group Analysis dengan pendekatan Parametric Test dan Welch-Satterthwait Test yang juga dapat dilakukan dengan aplikasi smartPLS. Hasil dari pengujian MGA dengan pendekatan parametric test adalah sebagai berikut:

Tabel 6 Hasil Uji Moderasi dengan Parametric Test

\begin{tabular}{lrrrrc}
\hline $\begin{array}{l}\text { Untuk Variabel Jenis } \\
\text { Kelamin }\end{array}$ & $\begin{array}{l}\text { Path Coefficients-diff } \\
\text { (Men vs Women) }\end{array}$ & $\begin{array}{l}\text { t-Value (Men } \\
\text { vs Women) }\end{array}$ & $\begin{array}{l}\text { p-Value (Men } \\
\text { vs Women) }\end{array}$ & Hasil \\
\hline $\begin{array}{l}\text { Financial Literacy } \rightarrow \\
\text { Risk Tolerance }\end{array}$ & 0,0642 & 0,9287 & $\mathbf{0 , 3 5 3 4}$ & $\begin{array}{c}\text { Tidak } \\
\text { Signifikan }\end{array}$ \\
\hline
\end{tabular}

\begin{tabular}{|c|c|c|c|c|}
\hline $\begin{array}{l}\text { Untuk Variabel } \\
\text { Status Pernikahan }\end{array}$ & $\begin{array}{l}\text { Path Coefficients-diff } \\
\text { (Married vs Single) }\end{array}$ & $\begin{array}{l}\text {-Value } \\
\text { (Married vs } \\
\text { Single) }\end{array}$ & $\begin{array}{l}\text { p-Value } \\
\text { (Married vs } \\
\text { Single) }\end{array}$ & Hasil \\
\hline $\begin{array}{l}\text { Financial Literacy } \rightarrow \\
\text { Risk Tolerance }\end{array}$ & $-0,0358$ & 0,4864 & 0,6269 & $\begin{array}{c}\text { Tidak } \\
\text { Signifikan }\end{array}$ \\
\hline
\end{tabular}

Sumber: Output SmartPLS 3.2.9, diolah peneliti (2020)

Berdasarkan Tabel di atas, diketahui bahwa hasil uji hipotesis dengan pendekatan parametric test untuk kedua variabel moderator, jenis kelamin dan status pernikahan, menghasilkan nilai $\mathrm{t}$ values $<1,96$ dan $\mathrm{p}$ values $>0,05$. Hal ini 
mengindikasikan bahwa tidak ada perbedaan pengaruh usia dan juga jenis kelamin pada pengaruh antara literasi keuangan dan toleransi risiko.

Lebih lanjut lagi, hasil dari pengujian MGA dengan pendekatan WelchSatterthwait Test adalah sebagai berikut:

Tabel 4.1 Hasil Uji Moderasi dengan Welch-Satterthwait Test

\begin{tabular}{|c|c|c|c|c|}
\hline $\begin{array}{l}\text { Untuk Variabel Jenis } \\
\text { Kelamin }\end{array}$ & $\begin{array}{l}\text { Path Coefficients-diff } \\
\text { (Men vs Women) }\end{array}$ & $\begin{array}{l}\text { t-Value (Men } \\
\text { vs Women) }\end{array}$ & $\begin{array}{l}\text { p-Value (Men } \\
\text { vs Women) }\end{array}$ & Hasil \\
\hline $\begin{array}{l}\text { Financial Literacy } \rightarrow \\
\text { Risk Tolerance } \\
\end{array}$ & 0,0642 & 0,9290 & $\mathbf{0 , 3 5 3 7}$ & $\begin{array}{c}\text { Tidak } \\
\text { Signifikan } \\
\end{array}$ \\
\hline $\begin{array}{l}\text { Untuk Variabel } \\
\text { Status Pernikahan }\end{array}$ & $\begin{array}{l}\text { Path Coefficients-diff } \\
\text { (Married vs Single) }\end{array}$ & $\begin{array}{l}\text {-Value } \\
\text { (Married vs } \\
\text { Single) }\end{array}$ & $\begin{array}{l}\text { p-Value } \\
\text { (Married vs } \\
\text { Single) }\end{array}$ & Hasil \\
\hline $\begin{array}{l}\text { Financial Literacy } \rightarrow \\
\text { Risk Tolerance }\end{array}$ & $-0,0358$ & 0,5086 & 0,6114 & $\begin{array}{c}\text { Tidak } \\
\text { Signifikan }\end{array}$ \\
\hline
\end{tabular}

Berdasarkan Tabel di atas, diketahui bahwa hasil uji hipotesis dengan pendekatan Welch-Satterthwait Test untuk kedua variabel moderator, jenis kelamin dan status pernikahan, menghasilkan nilai $\mathrm{t}$ values $<1,96$ dan $\mathrm{p}$ values $>$ 0,05. Hal ini mengindikasikan bahwa tidak ada perbedaan pengaruh usia dan juga jenis kelamin pada pengaruh antara literasi keuangan dan toleransi risiko.

Berdasarkan pengujian tambahan untuk melihat efek moderasi jenis kelamin dan status pernikahan terhadap pengaruh literasi keuagan dengan toleransi risiko maka diketahui bahwa ketiga pendekatan yang digunakan (PLS-MGA, parametric test dan Welch-Satterthwait Test) menghasilkan pengaruh yang tidak signifikan. Dengan demikian Hipotesis H8 dan hipotesis H9 tidak diterima.

\section{KESIMPULAN DAN SARAN}

\section{Kesimpulan}

Berdasarkan hasil analisis data dan pengujian hipotesis dalam penelitian ini maka dapat ditarik beberapa kesimpulan sebagai berikut : 1). Pendidikan Keuangan berpengaruh signifikan positif terhadap Pengetahuan Keuangan. Semakin tinggi pendidikan keuangan yang diperoleh para pekerja muda di Indonesia, maka semakin tinggi tingkat pengetahuan keuangan mereka. Begitupun 
sebaliknya, semakin rendah pendidikan keuangan yang diperoleh para pekerja muda di Indonesia, maka semakin rendah tingkat pengetahuan keuangan mereka 2). Pengetahuan keuangan berpengaruh signifikan positif terhadap Sikap Keuangan. Semakin tinggi tingkat pengetahuan keuangan para pekerja muda di Indonesia, maka semakin baik sikap keuangan mereka. Begitupun sebaliknya, semakin rendah tingkat pengetahuan keuangan para pekerja muda di Indonesia, maka semakin kurang baik sikap keuangan mereka. 3). Pengetahuan keuangan berpengaruh signifikan positif terhadap Perilaku Keuangan. Semakin tinggi tingkat pengetahuan keuangan para pekerja muda di Indonesia, maka semakin baik perilaku keuangan mereka. Begitupun sebaliknya, semakin rendah tingkat pengetahuan keuangan para pekerja muda di Indonesia, maka semakin kurang baik (buruk) perilaku keuangan mereka. 4). Sikap keuangan berpengaruh signifikan positif terhadap Perilaku Keuangan. Semakin baik sikap keuangan para pekerja muda di Indonesia, maka semakin baik pula perilaku keuangan mereka. Begitupun sebaliknya, semakin kurang baik (buruk) sikap keuangan para pekerja muda di Indonesia, maka semakin kurang baik (buruk) pula perilaku keuangan mereka. 5). Pengetahuan keuangan berpengaruh signifikan positif terhadap Perilaku Keuangan melalui Sikap Keuangan. Semakin tinggi tingkat pengetahuan keuangan para pekerja muda di Indonesia, maka semakin baik sikap keuangan mereka, dan semakin baik pula perilaku keuangan mereka. Begitupun sebaliknya, semakin rendah tingkat pengetahuan keuangan para pekerja muda di Indonesia, maka semakin kurang baik (buruk) sikap keuangan mereka, dan semakin kurang baik (buruk) pula perilaku keuangan mereka. 1). Perilaku keuangan berpengaruh signifikan positif terhadap Literasi Keuangan. Semakin baik perilaku keuangan para pekerja muda di Indonesia, maka semakin tinggi tingkat literasi keuangan mereka. Begitupun sebaliknya, semakin kurang baik (buruk) perilaku keuangan para pekerja muda di Indonesia, maka semakin rendah tingkat literasi keuangan mereka. 2). Literasi keuangan berpengaruh signifikan positif terhadap Toleransi Risiko. Semakin tinggi tingkat literasi keuangan para pekerja muda di Indonesia, maka semakin tinggi toleramsi risiko mereka. Begitupun sebaliknya, semakin rendah tingkat literasi keuangan para pekerja muda di Indonesia, maka semakin 
rendah toleransi risiko mereka. 3). Tidak terdapat perbedaan yang signifikan dari aspek jenis kelamin terhadap pengaruh Literasi keuangan terhadap Toleransi Risiko. Pekerja muda di Indonesia baik pria maupun wanita mempengaruhi sama besar antarapengaruh literasi keuangan terhadap toleransi risiko 4). Tidak terdapat perbedaan yang signifikan dari aspek status pernikahan terhadap pengaruh Literasi keuangan terhadap Toleransi Risiko. Pekerja muda di Indonesia baik yang masih single (belum menikah, janda/duda/cerai mati) ataupun yang sudah menikah mempengaruhi sama besar antara pengaruh literasi keuangan terhadap toleransi risiko

\section{Saran}

Adapun saran yang diberikan peneliti agar dapat dijadikan pertimbangan dalam pengembangan ataupun penyempurnaan penelitian selanjutnya antara lain adalah: 1). Penelitian selanjutnya agar dapat mempertimbangkan variabel demografi lainnya sebagai variabel moderator, seperti usia atau suku bangsa. Dapat pula memasukkan variabel moderator non-kategorikal seperti pengaruh orang tua atau religiosity. 2). Penelitian selanjutnya juga dapat memperluas subjek penelitian yang mencakup keseluruhan populasi di Indonesia, tidak terbatas hanya pada pekerja muda saja, sehingga hasil penelitian dapat lebih tergeneralisir. 3). Penelitian selanjutnya dapat memodifikasi model penelitian dengan menambah variabel lain sebagai variabel independen ataupun variabel intervening yang berkorelasi dengan literasi keuangan dan toleransi risiko, seperti variabel financial decision. 4). Penelitian selanjutnya juga dapat mengembangkan hipotesis penelitian ini dengan menguji secara langsung, pendidikan keuangan, pengetahuan keuangan dan sikap keuangan terhadap literasi keuangan, baik secara parsial maupun simultan. 5). Penelitian selanjutnya juga dapat mengukur toleransi risiko keuangan bukan hanya sebagai one-dimensional tapi sebagai multidimensional dengan memasukkan dimensi risiko seperti risk attitude dan risk capacity. 6). Penelitian selanjutnya juga dapat mempertimbangkan menggunakan tehnik analisis data lainnya seperti analisa regresi atau mencoba pendekatan kualitatif dalam menginvestigasi literasi keuangan dan toleransi risiko. 


\section{DAFTAR PUSTAKA}

Agustina, Ria Hayyu. "Pengaruh Financial Literacy Dan Risk Tolerance Pada Perilaku Pengelolaan Keuangan Di Surabaya," 2014.

Atkinson, Adele, and Flore-Anne Messy. "Measuring Financial Literacy: Results of the OECD INFE Pilot Study." OECD Working Papers on Finance, Insurance and Private Pensions, no. $15 \quad$ (2012). https://doi.org/10.1111/j.1745-6606.2010.01170.x.

Chen-Chen Yong, Siew-Yong Yew, Chu-Kok Wee. "Financial Knowledge and Behaviour of Working Adults in Malaysia." Margin 9, no. 1 (2015): 18-38. https://doi.org/10.1177/0973801014557392.

Cude, Brenda J, Frances C. Lawrence, Angela C. Lyons, Kaci Metzger, Emily LeJune, Loren Marks, and Krisanna Machtmes. "Eastern Family Economics and Resource Management Association College Students and Financial Literacy: What They Know and What We Need to Learn." Proceedings of the Eastern Family Economics and Resource Management Association 102, no. 9 (2006): 106-9.

Grable, Je, and Sh Joo. "Environmental and Biopsychosocial Factors Associated with Financial Risk Tolerance." Journal of Financial Counseling and Planning 15, no. 1 (2004): 73-82.

Grable, John E. "Financial Risk Tolerance." Handbook of Consumer Finance Research, 2016, 1-424. https://doi.org/10.1007/978-0-387-75734-6.

Griffin, R.W. Management Jilid 1. Jakarta: Erlangga, 2002.

Hayhoe, Celia Ray, Lauren Leach, and Pamela R Turner. "Discriminating the Number of Credit Cards Held by College Students Using Credit and Money Attitudes Q" 20 (1999): 643-56.

Herdjiono, Irine, Lady Angela Damanik, and Universitas Musamus. "Pengaruh Financial Attitude, Financial Knowledge, Parental Income Terhadap Financial Management." Jurnal Manajemen Teori Dan Terapan 9, no. 3 (2016): 226-41.

Hersh Shefrin. Beyond Greed and Fear: Understanding Behavioral Finance and Psychology of Investing. Harvard Business School Press, 2010.

Hilgert, Marianne A., Jeanne M. Hogarth, and Sondra G. Beverly. "Household Financial Management: The Connection Between Knowledge and Behavior." 
Federal Reserve Bulletin, 2003, 309-22.

Hogarth, Jeanne M. "Financial Education and Economic Development," 2006.

Huang, Jin, Yunju Nam, and Margaret S. Sherraden. "Financial Knowledge and Child Development Account Policy: A Test of Financial Capability." The Journal of Consumer Affairs 47, no. 1 (2013): 1-26.

Hung, Angela A., Andrew M. Parker, and Joanne K. Yoong. "Defining and Measuring Financial Literacy." Social Science Research Network, 2009. https://doi.org/10.2139/ssrn.1498674.

Huston, Sandra J. "Measuring Financial Literacy." Journal of Consumer Affairs 44, no. 2 (2010): 296-316. https://doi.org/10.1111/j.17456606.2010.01170.x.

Joseph F. Hair, Jr, William C. Black, Barry J. Babin, and Rolph E. Anderson. Multivariate Data Analysis. 7th Editio. New Jersey: Pearson Education, Inc, 2010.

Loke, Yiing Jia. "Financial Knowledge and Behaviour of Working Adults in Malaysia." The Journal of Applied Economic Research 9, no. 1 (2015): 18 38. https://doi.org/10.1177/0973801014557392.

Lusardi, Annamaria, and Olivia S. Mitchell. "Financial Literacy and Retirement Planning in The United States." NATIONAL BUREAU OF ECONOMIC RESEARCH, 2011. https://doi.org/10.1017/CBO9781107415324.004.

Marsh, Brent A. "Examining the Personal Finanial Attitudes, Behavior and Knowledge Levels of First-Year and Senior Students at Baptist Universities in the State of Texas." Bowling Green State University Political Science, 2006.

Pankow, Debra. "Values, Attitudes and Goals," 2003.

Pertiwi, mega mutiara, Universitas Islam. "Pengaruh Finance Literacy Dan Faktor Demografi," 2018.

Potrich, Ani Caroline Grigion, Kelmara Mendes Vieira, and Guilherme Kirch. "Determinants of Financial Literacy: Analysis of the Influence of Socioeconomic and Demographic Variables." Revista Contabilidade $e$ Financas 26, no. 69 (2015): 362-77. https://doi.org/10.1590/1808$057 \times 201501040$.

Potrich, Ani Caroline Grigion, Kelmara Mendes Vieira, and Wesley Mendes-DaSilva. "Development of a Financial Literacy Model for University Students." Management Research Review 39, no. 3 (2016): 356-76. https://doi.org/10.1007/978-3-319-91911-9_4.

Putri, Ni Made Dwiyana Rasuma, and Henny Rahyuda. "Pengaruh Tingkat Financial Literacy Dan Faktor Sosiodemografi Terhadap Perilaku Keputusan Investasi Individu." E-Jurnal Ekonomi Dan Bisnis Universitas Udayana 6, 
no. 9 (2017): 3407-34.

Rajna, Anthony, WP Sharifah Ezat, Syed Al Junid, and H Moshiri. "Financial Management Attitude and Practice among the Medical Practitioners in Public and Private Medical Service in Malaysia." International Journal of Business and Management 6, no. 8 (2011): 105-13.

Ramachandran, Ramakrishnan. "Financial Literacy - The Demand Side of Financial Inclusion." SSRN Electronic Journal, 2011. https://doi.org/10.2139/ssrn.1958417.

Riris. “Alasan Mengapa Milenial Perlu Berinvestasi?” Artikel Ilmiah, 2019. https://ajaib.co.id/alasan-mengapa-milenial-perlu-berinvestasi/.

Santini, Fernando De Oliveira, Wagner Junior Ladeira, Frederike Monika Budiner Mette, and Mateus Canniatti Ponchio. "The Antecedents and Consequences of Financial Literacy: A Meta-Analysis." International Journal of Bank Marketing, 2019. https://doi.org/10.1108/IJBM-10-2018-0281.

Sinha, Shubhra Biswas, and Arindam Gupta. "Financial Inclusion and Financial Literacy: A Comparative Study in Their Interrelation between Selected Urban and Rural Areas in the State of West Bengal." IOSR Journal of Economics and Finance, 2013, 67-72.

Vieira, Kelmara Mendes, Ani Caroline Grigion Potrich, and Wesley Mendes-DaSilva. A Financial Literacy Model for University Students. Individual Behaviors and Technologies for Financial Innovations, 2018. https://doi.org/10.1007/978-3-319-91911-9_4.

Yong, Chen Chen, Siew Yong Yew, and Chu Kok Wee. "Financial Knowledge, Attitude and Behaviour of Young Working Adults in Malaysia." Institutions and Economies 10, no. 4 (2018): 21-48. 